\title{
TWO-STAGE COOKING AS A METHOD OF IMPROVING THE NUTRITIVE VALUE OF JACKBEAN (Canavalia ensiformis) FOR BROILERS
}

\author{
A.B.I. UDEDIBIE; B.O. ESONU; C. UNACHUKWU AND N.C. IWUOHA, \\ Department of Animal Production, Federal University of Technology, Owerri.
}

Received 20 March 19\%; Accepted $6 \mathrm{Mm}$, $19 \%$

\begin{abstract}
A 4 - week feeding trial was conducted to determine the effect of 2 - stage cooking on the uturitive value of jackbean (Canavalia ensifomis) for brollers. Two-stage cooking is ene of the practices employed in the villages for preparing toxic foodstuffs for human consumption. Jackbeans were cooked for $\mathbf{4 0}$ minutes at the end of which the cooking water was thrown out. Fresh water was added and the cooking continued thereafter for another $\mathbf{4 0}$ minutes. The two-stage cooked jackbeans were then dried, ground and included in broiler finisher diet at $0,10,15$ and $20 \%$ levels, respectively, and each diet fed to 30 broiler chikckens for 4 weeks. There were no significant $(P<0.05)$ dinerences in feed intake, growth rate and feed conversion ration among the four experimental groups.

Key words: Jackbean, 2-stage cooking, Nutritive value, broilers.
\end{abstract}

\section{ITRODUCTION}

Jackbean (Canavalia ensiformis) has been identified as an indigenous legume which has shown promise as energy and protein source for livestock production in view of its high seed yield and protein content. Jackbean seed yields of 25 - 3.0 tha have been reported in Zimbabwe (Addison, 1957), Dominican Republic (Pound et at, 1982), Venequela (MOra and Para, 1980), Mexico (Herrera, 1991) and in Northern Nigeria (Okonkwo and Udedibie, 1991). These yields are comparable to that of soybean grown under temperate conditions. the white seeds are relatively large, about $2-3 \mathrm{~cm}$ in diameter, 5 times the size of soybean and contains up to $30 \%$ crude protein.

Jackbean, however, contains toxic subetances which limit its use as feed ingredient for noo-ruminants to only 5\% dietary level (D'Mello et al., 1995; Udedibie and Madubuike, 1988; Udedibie and Nwaiwu 1988; Wyss and Bickel, 1988). The best known of these substances is Concanavalin A (Con A), a lectin (Hague, 1975; Jaffe, 1980), which has been reported to have negative effects on nutrient digestion and absorpdtion (Liener, 1986; Sandholm et al., 1976). Earlier attempts at improving its nutritive value so as to render it valuable as a protein and energy supplement for poultry have demonstrated that heat treatment alone could not significantly destroy the anti-nutritional factors in it (Udedibie and Nwaiwu, 1988; Udedible and Madubuike, 1988; Udedibie and Nkocha, 1990). Treatment with urea followed by heating has now been established as one effective method of detoxifying it (Montilla et al., 1981; Udedibie and Nkwocha, 1990; Udedibie et al., 1994).

Two-stage cooking is a practice commonly employed locally for preparing certain poisonous foodstuffs for human consumption. It involves changing the cooking water half way during the cooking and continuing the cooking thereafter with fresh water. The trial herein reported was therefore designed to test its efficacy as a method of improving the nutritive value of the jackbean for broilers.

\section{MATERIALS AND METHODS}

Thie jackbeans used for study were produced at the substation of National Root Crops Research Institute (NRCRI), Vom, Plateau State. The jackbeans were cocked in 2 stages. First, the Jackbeans were sub-merged in water and cooked for 40 minutes. Period of cooking was taken as starting from the point of boiling. At the end of the $\mathbf{4 0}$ minutes, the water was thrown out. Fresh water was added and the cooking continued for another $\mathbf{4 0}$ minutes during which 
UDEDIBIE ET AL

TABLE 1: INGREDIENT COMPOSITICN OF THE EXPERIMENTAL DISTS

\begin{tabular}{|c|c|c|c|c|}
\hline Ingrealinese (1) & a. & $\begin{array}{l}\text { Diotar } \\
\text { 10.0. }\end{array}$ & 150 (n) & 20 \\
\hline Maine & 55.0 & 50.0 & 55.0 & 40 \\
\hline Jantberen & $\cdot$ & 10.0 & 15.0 & $\mathbf{2 0 0}$ \\
\hline Soybean meal & $\mathbf{1 5 . 0}$ & 12.5 & 12.5 & 12.5 \\
\hline Groundnut Cake & 5.0 & 4.0 & 4.0 & 4.0 \\
\hline Palm kemel cake & 6.5 & 5.0 & 5.0 & 50 \\
\hline Premix* & 18.5 & 18.5 & 18.5 & 185 \\
\hline \multicolumn{5}{|c|}{ Cheralea Conmonem (\% of DM) } \\
\hline Crude Prowin & 19.2 & 19.4 & 19.8 & $\mathbf{2 n 1}$ \\
\hline Crude fitore & 5.6 & 5.6 & 5.7 . & 58 \\
\hline Ether Extract & 5.3 & 5.2 & 5.2 & 5.1 \\
\hline Cajcium & 1.4 & 1.3 & 1.3 & 1.2 \\
\hline Phosphorus & 0.8 & 0.8 & 0.7 & $a 7$ \\
\hline $\mathrm{ME}(\mathrm{Kcal} / \mathrm{g})$ & 2.8 & 2.8 & 2.8 & 28 \\
\hline
\end{tabular}

the beans became fairly soft. The beans were then dried over-night in the oven at $70^{\circ} \mathrm{C}$ and milled. Samples of raw and the cooked jackbean meals were subjected to chemical analysis (AOAC, 1980) to determine the effect of the processing method on the nutrients contents, using 3 replicates per sample.

The processed jackbean meal was then used to formulate broiler finisher diets at $0,10,15$ and 20 percent dietary levels, respectively (Table 1). which were fed to the broilers for 28 days.

One hundred and twenty 3-week old broilers of Anak strain were divided into 4 groups of 30 birds each and the groups randomly assigned to the four experimental diets. Each group was further sub-divided into 2 replicates of $\mathbf{1 5}$ birds and each replicate kept in a $2 \mathrm{~m} \times 4 \mathbf{m}$ compartment. Feed and water were provided ad libitum. Feed intake was recorded daily and the birds were weighed weekly. Other management routines like vaccination against New castle disease at day old, prophylactic treatment against coccidiosis with Amprolium at 3-weeks of age and vaccination against Gumboro at 4 weeks were carried out. The data collected were subjected to Analysis of Variance (Snedecor and Cochran, 1967)

\section{RESULTS AND DISCUSSION}

\section{Chemical Composition at 2-Stage Cooked Jackbean}

The chemical composition of raw and 2-stage cooked jackbean meals is shown in Table 2. Jackbeans lost $\mathbf{1 4 . 4}$ and $\mathbf{1 7 . 5}$ percent of its crude protein and fibre contents respectively, in the course of the 2-stage cooking. Other nutrients were not significantly $(P>0.05)$ affected by the processing method. This seems to agree with earlier observations at this station (Udedibic and Nwaiwu, 1988) which indicated that when cooked or autoclaved, some nitrogenous substances in jackbean are solubilized and removed. Extent of solubilization of nitrogenous substance in the jackbean appeared higher with 2-stage cooking as one hour cooking resulted in orly $7 \%$ solubilization (Udedibie and Nwaiwu, 1988).

\section{Performance of Experimental-Birds}

Data on the performance of the experimental birds are summarized in Table 3. There were no significant $(P>0.05)$ differences in the performance of the birds in all the measurements examined i.e growth rate, feed intaks and feed conversion ratio. Only one bird died in the $10 \%$ jackbean group, 
TABLE 2: ENERGY CONTENT AND CHEMICAL COMPOSITION OF RAW AND 2-STAGE COOKED JACKBEANS* (\% OF DM)

\begin{tabular}{llll}
\hline Conctinents & Raw Jackbean & Cooked Jackbean & SEM \\
\hline Crude Protein & $28.46^{\mathrm{a}}$ & $24.37^{\mathrm{b}}$ & 1.22 \\
Crude Fibre & $7.81^{\mathrm{a}}$ & $6.44^{\mathrm{b}}$ & 0.26 \\
Exher Extract & 3.06 & 3.02 & 0.10 \\
Total Ash & 3.71 & 3.74 & 0.31 \\
Calcium & 0.14 & 0.12 & 0.002 \\
Phosphorus & 0.71 & 0.70 & 0.001 \\
Gross Encrgy (Kcal/g) & 4.70 & 4.61 & 0.17 \\
\hline
\end{tabular}

-All values expressed on $100 \%$ dry matter basis.

representing a mortality percent of $3.30 \%$. The results of this trial contradicted earlier observation that heat treatment alone could not appreciably improve the nutritive value of jackbeans (Udedibie and Madubuike, 1988, Udedibie and Nkwocha, 1990; Udedibie et al., 1994). Earlier studies at this station involving autoclaving, one hour straight cooking or toasting showed that those methods could improve the nutritive value of jackbean only to the extent of $10 \%$ dietary level of inclusion for poultry.

Jackbean contains toxic elements which limit its use as feed ingredient for non-ruminants. Jackbean has been reported to contain, in addition to thermolabile inhibitory substances, thermostable anti-nutritional factors such as Canavaline and Canaline (Rosanthel, 1972), Canatoxin (a haemagglutinatin toxic protein (Carlini and Guimaraes, 1981) and more importantly Concanavalin A (Con A) (Hague, 1975, Jaffe, 1980) which is a lectin. Lectins are reported to negatively affect nutrient utilization by different mechanisms including binding to the glycoproteins and glycolipids of the digestive tract mucous (Hague, 1975; Jaffe, 1980), inhibition of the activity of enzymes of the brush border of enterocytes (Rosanthel, 1972) and interferring with the adherence of enterobacteria to the intestinal wall (Jayne William, 1973). These anti-nutritional factors are nitrogen-containing compounds.

The mode of action of 2-stage cooking on these factors cannot totally and readily be explained. However, it is known that heat denatures proteins, thereby destroying their biological activities. This is mostly applicable to the thermolabile ones. Although the nature of the solubilized nitrogenous compounds arising from this process was not determined, it is likely that the thermostable factors in the jackbean formed a good proportion of the solubilized and removed nitrogenous compounds. This might have been partly responsible for the improvement in the nutritive value of the jackbean so processed. Whether extended period of cooking in the

TABLE 3: EFFECT OF 2 - STAGE COOKING ON THE NUTRITIVE VALUE OF THE JACKBEAN FOR BROILERS

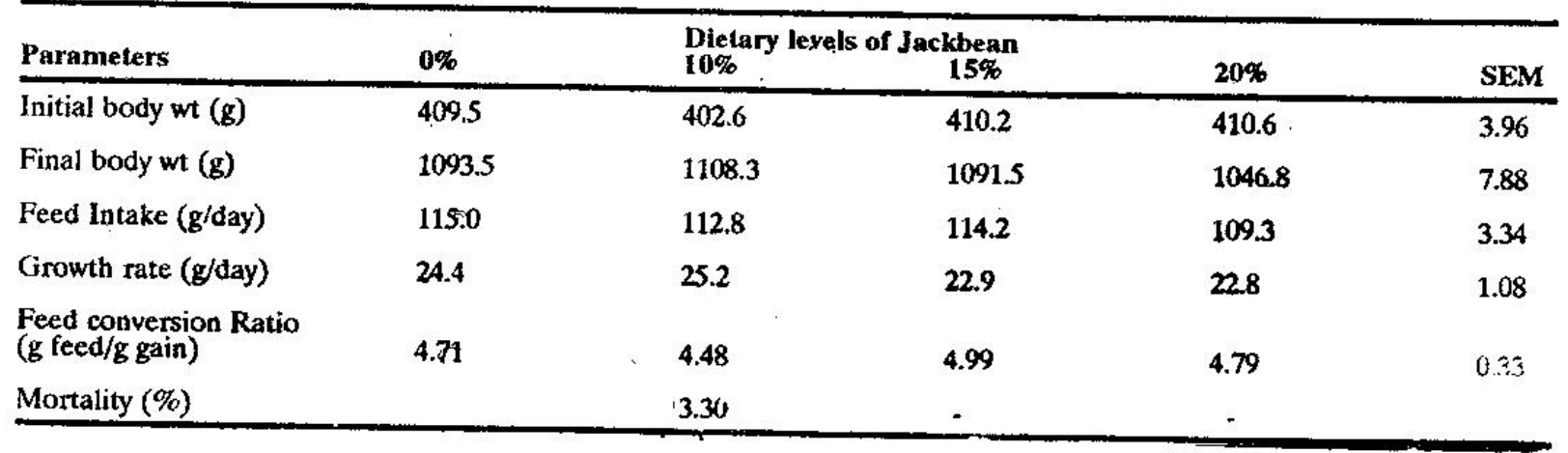


2-stage cooking process will result in further improvement on the nutritive value of the jackbean is not known. This will therefore form part of our focus in future investigations.

\section{REFERENCES}

ADDISON, K.B. (1957). The effect of fertilizing, espacement and date of planting on the yield of jackbean (Canavalia ensiformis). Rhodesian Agric. J., 54:521 - 532.

AOAC. (1980). ASSOCIATION OF OFFICIAL ANALYTICAL CHEMISTS Official Methods of Analysis. 13th edn., Washington DC.

CARLINI, C.R. and I. GUIMARAES. (1981), Isolation and Characterization of a toxic protein from Canavalia ensiformis (jackbeans) seeds distinct from Con $A$. Toxicol., 19: 667 - 675 .

D'MELLO, J.P.F., ACAMOVIC T. and WALKER A. G. (1985). Nutritive value of jackbean (Canavalia ensifornis) for young broiler chicks. Trop. Agric. (Trinidad). 62: $145 \cdot 150$.

HAGUE, D. (1991). Studies of storage protein of higher plants. I. Concanavalia A from three species of the genus canavalia. Plant Physiol., 55 : 636 - 642.

HERRERA, F. (1991). Personal communication. facultad de Medicina Vet. Zootecnia Univ. de yacatan, Mexico.

JAFFE, W.G. (1980). Hemaglutinins (Lectins). In: Toxic constituents of plant foodstuffs. Liener, I.E. (ed.), Acad. Press. NY. PP. 73 102.

JAYNE - WILLIAM, D.J. (1973). The influence of dietary Jackbean (Canavalia ensiformis) and Con-canavalin $A$ on the growth of conventional and gnotobiotic Japanese quail. Nature New Biol. 243: 150 15.1.

LIENER, I.E. (1986). Nutritional significance of lectins in the diet. In: The Lectins. Liener, I. E. et al (eds.) Academic Press Inc., New York, P. 525 - 552.

MORA, M and PARA. R. (1980). Resultados Preliminares del creimiento do la leguminosa (Canavalia ensiformis). Resultados no publicadon instituto de production Animal Facultad de Agronoma Univ. Central de Venezuela.

MONTILLA, J.J., PERREIORO, M. CUPUL, S. GUIARREZ M. and PRESTON, T.R. (i981). Preliminary observation: The effect of ensilage and heat treatment of Canavalia ensiformis seeds in diets for poultry. Trop. Anim. Prod., 6: 376 - 377.

OKONKWO, J.C. and UDEDIBIE. A.B.I. (1991). Preliminary observation on the yield performance of jackbeans (Canavalia ensiformis) in the Guinea Savannah of Nigeria. Paper presented at the 27th Ann. Conf., Agric. Soc. of Nig. Minna - Nigeria, 1st - 4th Sept., 1991. pp. 10 - 11.

POUND, B., DONA F. and PERATTA. G. (1982). Effect of citting frequency on seed and forage yield of Canavalia ensifomis (jackbeans). Trop. Anim. Prod., 7:262 - 266. ROSANTHEL, G.A. (1972). Investigations of Canavalin biochemistry in the jackbean plant. II. Canavalin biochemistry in the developing plant. Plant Physiol., 50: 328 - 331.

SANDHOLM, M., SMITH, R. SHIN R.R. and SCOTT. M.L. (1976). Determination of anti-trypsin activity on agar plates. Relationship between trypsin and biological value of soybean for trout. J. Nutr., 106: 716 772.

SNEDECOR, G.W. and COCHRAN. W.G. (1967). Statistical Methods. The Iowa State Univ. Press, Ames., Iowa, 6th edn.

UDEDIBIE, A.B.I., ESONU, B.O. OBAJI C.N. and DURUNNA. C.S. (1994). Dry urea treatment prior to toasting as a method of improving the nutritive value of the jackbean (Canavalia ensiformis) for broilers. Anim. Fd. Sci. Tech., 48: 335 - 344.

UDEDIBIE, A.B.I. and MADUBUIKE. F.N. (1988). Effect of dietary raw and cooked jackbeans (Canavalia ensiformis) on the performance of laying hens. J. Arid Agric., 1: $47-54$.

UDEDIBIE, A.B.I. and NKWOCHA. C.O. (1990). Comparative study of jackbean (Canavalia ensiformis) and swordbean (Canavalia gladiata) as protein supplements for young broiler chicks. Nig. Agric. J., 24: 7. 14.

UDEDIBIE, A.B.I. and NWAIWU. J. (1988). The potential of Jackbean (Canavalia ensiformis) as animal feed. Nig. Agric. J., 23: $118-129$.

WYSS, U. and BICKEL H. (1988). Ripe beans of Canavalia ensiformis (jackbean) as feed ingredient for monogastric animals. Anim. Feed Sci. Tech., 20: 325 - 326. 